\title{
Work in a Performing Ephemeral Environment
}

\author{
Carlos César Ronchi
}

Department of Management

Ceuma University

\author{
Mauro Enrique Carozzo Todaro \\ Department of Mechanical and Industrial Engineering \\ State University of Maranhão
}

\begin{abstract}
The aim is to present a construct, which contributes to increase understanding about work and the career in a liquid society. Based on the centrality of work, the individuals are each day more imprisoned to a life restricted to organizations. It is also desired to present facets regarding to organizational restriction and construction of a language that has it as a perfect object. In this condition, the organizational actors seek refuge in this illusions shelter. In this high performance environment, companies and individuals try making their own edition of the ideal world. These representations show that the individuals assume as normal the hegemonic position of power of organizations. This article does not aim proving or refuting any theory, neither suggest modifications but deconstruct the organizational imaginary and its contradictory speeches about work in the liquid society. However, in view of this, some parameters may be set in order to decrease the discursive dissimulation and violence at work.
\end{abstract}

Keywords: Work. Career. Organizations. High performance environment.

\section{INTRODUCTION}

This article aims to make criticisms to the representations in which work is inserted in a performing ephemeral time, from a theoretical approach among several writers (DEBORD, 1983; BAUDRILLARD, 1995; HARVEY, 1998; BAUMAN, 2004, 2007; LLOSA, 2013; LIPOVESTKY, 2005) about the fluid society and its illusory intercurrence in individual lives. The essay also intends to structure the work and its ramifications in the corporate environment and part of the following premises: increasingly, the living is substituted by the representation; life is no longer lived only to be represented; and the word is subordinated to the performing image in a liquid environment. These arguments in the spectacle society find in the organization a promising environment for individual's resonance and of society itself.

The organization is realized as the one who structures itself in a 'planned subjectivity', even understanding that individuals are not passive recipients, but they act on this condition as 'actors'. This conception is intentional, because it is structured in the perspective of these actors represent their texts (DEJOURS, 2004), since the work shows itself as a potent device of subjectivity. These texts operate in speeches built of images and artefacts that permeate and want to offer meanings and adherence to the actors.

This totalitarian modality of organizations can be widely noticed mainly in the pop-management literature (WOOD JR \& DE PAULA, 2002) which voices a continuous excellence environment. In a society that suffers of individualization outbreak (LIPOVETSKY, 2005), the organization starts 'having life and being human', bearer of purposes and the one who leads its employees to excellence, to conquest in the arena where constant fights are articulated to beat the competition. This configuration condition the individual to professional growth from its skill, to assume or preserve positions with effective contribution for organizational goals. It follows that, the individual for itself, must become a company (GORZ, 2005).

In this dynamics, it is inferred that, the organization became liquid, too. The organization is frequently loved and hated at once, something similar to what is called love-fusion (ENRIQUEZ, 1997). 
Essentially, structured on utilitarian calculations, the organization becomes an arena where its actors strive in order to maximize their gains ${ }^{1}$. This logic presents subtle domination that must be understood as a state of affairs in which the actions from dominated appear as if they have embraced its content of will manifested from the dominant (GUERREIRO RAMOS, 1981).

This domination generates refractory pressure of 'to be, acquiring seductive powers from a promise of incalculable pleasures with no addition of incalculable risks (BAUMAN, 2005). In this perspective, the relationship of individuals with the organizations is less perennial, and need to be always fed (PRESTES MOTTA, 1978); in this context, the private space is invaded by the managerial activity (GAULEJAC, 2007). The organizations model themselves to be a worldview and its speech overvalues the action, inflates the permanent adaption, always proposes challenges, unlimited power, arena of achievement, where progress must be constant. In this perspective, the laws of system never take a vacation (BAUDRILLARD, 1970).

The consequences of this action and of this speech promote a perverse assembling (CALLIGARIS, 1986), an imaginary omnipotence, a perfect object for identification and investment. On behalf of organization, everything is possible and, for it, everything is justified, revitalizing the myth of organizational immortality. Thus, the future, frighteningly unknown and impenetrable becomes more palatable. Anyway, there is little to choose in this interminable, eternally endless and frustrating seek for sure. In the theoretical plan, this text constitutes a reflection that is registered in a questioning (BAUMAN, 2004). How deal with these conflicting and changing expectations of this organizational call? The opening has aspect of a precipice (BAUMAN, 2004, 2007), seductive and full of reverberations of omnipotence and magnanimity.

\section{Corporations: Planned Legal Fictions}

The nebula of illusions that features the current society, finds its origin since, approximately, seventy thousand years, in which the Cognitive Revolution was dominated (HARARI, 2015). Before this period of abrupt changes, the humans lived in small groups, between twenty and fifty individuals, as well as the chimpanzee still do. However, during that revolution, certain changes in these individuals' behavior are manifested in several explicit symbolic aspects of its culture (HARARI, 2015). The secret that facilitate the overcome of critical size of these groups, giving place to the creation of empires, religions, nations and corporations, is, probably, in the fiction.

In this performing society, in order that a great number of strangers cooperates effectively, it is necessary that they believe in the same myths (HARARI, 2015). Based on this premise, many companies invest lots of effort to convince people by means of 'old wives tales', beliefs generally accepted, not confirmed by facts, denominated as myths (LEEMING, 1992). One of these 'tales' present in this network of fictions is the one about the company as 'big family' (FLEURY, 1987). This myth reinforces the camaraderie climate, the trust and cooperation among scripted actors in search of organizational goals. The visible image of these organizations may result very seductive, but once within of the performance routines that it proposes, arises a hidden representation of domination and submission.

The corporations, at the same time as they reinforce certain myths aiming to orient the efforts of the 'cast', are, in themselves, a 'legal fiction'. To create this type of companies, the lawyer just need to carry out the needed rituals and, from this moment the society, instantaneously, will start to believe that the corporation exists. Many of them will invest money and others 'will give their lives' for it, even though this is just a role enchantingly decorated. This is based on the existence of beliefs shared by members from a society and, inasmuch as these beliefs persist, the fiction gains a powerful force.

This imaginative capacity has relegated the objective world to a background. Over the years, the tangle of fictions grew to the point in which the society is, with astonishing naturality, totally immerse in imagined realities. That artefact developed in the 19th century aiming to foster economic growth, called 'companies of limited responsibility', does not exist out of the collective imagination, but exerts powerful influence on the objective world. Therefore, as well as the objects are transformed into symbols of status, the corporations, more than an employment source, are symbolic spaces that seek to give sense to our lives.

Along the last decades, the political parties are not being so successful, as before, on the endeavor to create a fiction able to inspire the masses and make them to believe in a better life. Currently, instead of a better society, the great majority strives to improve its individual position in the society in which 
it is inserted (WILKINSON e PICKETT, 2015). It has allowed that corporations obtain greater power on the masses, while they offer status and purposes of life, by means of tempting career plans and bewildering visions. The publicity and institutional videos are seductive trailers that ensure incalculable pleasures, fruit of a planned subjectivity that generates hope and illusion, but not for the purpose of the actors 'live the dream', but 'to live in a dream'.

\section{CAREer: Renegade the FunCtion OF THE EPHEMERAL AND THE Fluid?}

In the abrupt abundance and in the evident impulse that self-perpetuates the career construction to fill social expectations combined with attempt to strengthen the self, the individual launches out such as a 'Don Quixote', to its fantasy and to the harsh reality, identifying in the own work a result particularly portentous and redeemer. The pop-management literature signals a life as business and its ideology is featured by the dramatization of human relationships and by the appreciation of the utilitarian dimension, to the detriment of human (WOOD JR, TONELLI \& COOKE, 2011). The organization became a repository of opportunities, but this domain created a distorting language, result of the prevalence of criteria in the social tessitura in its group, and dilution of the politic in the social context (GUERREIRO RAMOS, 1981). In this social context, the organizational actors are regularly subjected to tensions about their careers, and the need to manage them by adopting a living of submission and adhesion to a performing and fluid organizational life.

In these times, the individuals need to be great in everything (ENRIQUEZ, 1997), identifying, thus, with the organization strength (PRESTES MOTTA, 1978), since it holds a 'power of stage', sumptuous, opulent, extravagant and redeemer. It is a chart of references coherent and ambitious (PRESTES MOTTA, 1993), since the actors are recommended to demonstrate omnipresence and clear thoughts, to be able to answer the frequent and changing demands of the organization. Many people are influenced by perceptive deviations, and they commonly ignore factual data and change the definitions according to the circumstances. However, in this perspective, the actors are regularly subjected to conflicting and contradictory tensions, that not always can take them to question themselves about effectiveness of their practices.

The organizational speech and the media's constantly signals change in the work contract and in the conception of progression in the career, in a culture of long working times, in which private life is sacrificed. This new reality indicates that the actor must prepare itself to the "chaos of the career in the organization'. The organization becomes a fluid space, without spatial and temporal frontiers, which takes to the reconception of solid division established in the classical modernity between public and private. A rhetoric with a cinematographic and visual sophistication, a never free refinement, an idealized image that projects a mirage. The construction of a liquid career is lost in dense verbal and intellectual 'fogs' that confirm perceptive fantasies about a false identity, however, ratified by the speech of a narcissist society.

These 'fogs' are built in a language of a game of the spectacularization of career, full of ambiguities, contradictions, paradoxes and uncertainties, roughly organized around the perceptions coherent and inconsistent of meanings. In this dynamics, there is no time to build its identity; therefore, this condition leads the individual to assume the identity of the moment, ephemeral. This ephemerality imposes instability, ambiguity and contradictions at work, the actors will be frequently forced 'to make bricolage' and improvise, not necessarily evaluating well the consequences of their acts. In our world of furious individualization, the relationships are ambiguous blessings, oscillating between dream and nightmare, and there is no way to determine when one is transformed into another (BAUMAN, 2004).

In a performing society, how do not build a career full of status, assuming itself as an ideal model, loyal, of dedication and brilliance? How do not plan itself in a world that never existed, but that its actors desperately need to idealize and accept? The competition imposed disseminate fashion and modes that feed the career's fluidity, what becomes the individual even more paranoiac by the organizational gurus' novelties, their books and pop-management lectures (WOOD JR \& DE PAULA, 2002). It seems a choice, but is merely and identification contained in the moorings of the organizations and in a participation without autonomy, however, desired by the individual itself.

The ideology preponderant in the career construction signals the liberation. This freedom is sanctioned in such way that the options imposed are: to fit in or accept the exclusion. The manifestation attributes the individual the need of to fit in perceptions that are unrelated to it, by 
means of a stereotype that is demanded of it. In a way that, before the universal power, the life and the face of all individuals are transformed (ADORNO, 2002, p. 56). In this premise, the work becomes conditioned by competition and by 'customization' (BAUDRILLARD, 1970), transforming it into a utilitarian value, such as a product to be consumed. This customization creates illusion of originality, of the exercise of personal preference.

In the work plan, it was established the illusion of choice free of occupations (BAUDRILLARD, 1970). The organization intends to be an autonomous reality, dominator of environment and of the lives of their 'beings', who elect the work as their own life. This exclusivist power may work as a seductive arena, since the individuals put it in the location of their ideal of self, thus, the career can be object of love and source of imprisonment (PRESTES MOTTA, 2000).

\section{Work: A CONSTANT CALl FOR ITS Resignification}

The organizational actors live together in a flexible work environment, dynamic and impacting on the perspective of interaction standards, in interpersonal or professional relationships. The disordered and unlimited proliferation of competitive practices previously mentioned creates incantations able to reach considerable dimensions in the work environment. This environmental magnitude promises to transform professionals into protagonists, and they deliver themselves to a tour to the confines of words and performing practices. In this context, the work constitutes a central psychosocial phenomenon, multidimensional and dynamic that affects the social reality built and reproduced in its network of meanings and the subject constitution. It is necessary, in this perspective, to ratify that the conditions presented do not reduce themselves only to a labor binding, because the modeling of contemporaneous worker is beyond the employer-employee relationship. In the same way as the transforming strategies imposed by the organizations are admitted, in dual form, the performer professional legitimates itself in the functional eclecticism and in heterogeneous skills.

The work dynamics monitors the transformations occurred in an environment in which everything can be measured by time, and it, in turn, became the companies' greatest enemy (FREITAS, 2005). This dramaturgy of the productive process in organizational systems is reflected in one of the main paths for human achievement, since it can often mean, the individual's own identity, but in others creates an ephemeral character. The work configurations, imposed to the individuals, redefine the existential sense of this man, becoming it hostage of the organizational imagination, independently on its formal relation of linking. Thus, discover a sense in life can happen through the work or practicing an act (FRANKL, 1991). In contrast, this environment became more predatory, generating imbalances between personal and professional life.

The work relevance in the sphere of personal life can be measured by its importance for the majority of people and by the evident level of constant worry that permeating this subject. As well as, by the set of all observances related to the time, place and to the instruments that maximize a relation of uncertainty relating to the future. The organizations seduce and imprison, because they act as bearers of ideal of this performer professional, who acts in the construction of projects that aim to maximize the gain, but shows itself in the pseudo organizational 'divinity'. In this dimension, this imagination is voluntarily incorporated as being the individual's, since this structure based on control and perfection is what their members wish for their own ego. This individual seeks in the organization the sense of its existence, and a path that takes it to be incessantly loved (FARIA, 2007) and that can present meaningful and rewarding purposes.

The organization establishes itself in the order of things (initial regulation), demanding a series of new behaviors and positioning compared to the individual and its work relationships. Drawing on the survival need, in the guise of giving autonomy to the individuals, the organizational speech is ideological, always being spoken for someone who is asked 'to fight for its space'. This organizational environment imposes that only the 'heroes and warriors' can see what threat them (FREITAS, 2006), and moved by a passion, they have as 'mission' to fulfil its role: to fight, save, rescue, conquer and release.

This context imposes the systematic control of social relations in which the heroic acts are only objects; even they are called by merit or any configurations to make a difference. In this environment, the power to concretize belongs to the experts, who in a diffuse game of domain, appearances and theatricality mobilize all the energy. The organizational environment celebrates the performance culture, installing the generalized competition that induces to personal merit, since it privileges the winners to the detriment of the losers (GAULEJAC, 2007). 
The organizations are spaces of controlling that legitimate themselves by the resonance of the aesthetic and selective speech, not limiting only to formal controls, but making expand the informal relations. These indirect controls can be pointed as cultural practices of adhesion, permission and moral persuasion (CLEGG, 2007). The organizational speech is ideological, being always spoken to someone, in order to generate a direction and a sense implicated in its structure (CLEGG, 2007).

The instantaneous perception of things is linked to the idea of space. The organization physical space (with its formal qualities, that is, qualities sensorily perceivable) is, thus, the realistic picture of its cultural identity, and the artefacts constitute a vital strength for the organization evolution as culture (GAGLIARI, 2001, p. 135). The control of organizations is increasingly subtle and involving (FREITAS, 2000), in the attractiveness in the selection of people, or in the facets existing in the midst of the corporate functionality.

The language became only another instrument in the gigantism of the hypermodern society's reproductive system. The truth and ideas were radically functionalized, and the language is considered as a mere instrument, for the stocking and communication of production intellectual elements, or for orientation of masses (ADORNO \& HORKHEIMER, 1985). This type of language is useful such as a heuristic resource, since the individuals no longer realize the process in which they were coopted or seized. Then, the controlling dynamics moves from the physical system to the psychic system, channelizing subjectivity (GAULEJAC, 2007), since it becomes difficult to deny the acting in this frontier.

Thus, in this perspective, the individual can fantasize a union with the organization that provides to them the illusion of totality or fullness, that is, the feeling of a relationship without failures, in which all its goals are satisfied (FREITAS, 2000). The emphasis in the ephemerality concentrates in expressing or representing the 'eternal mutable', however engendered in its web, being difficult to repudiate such a expectation of living in an excellence environment, the 'dream of omnipotence' (ENRIQUEZ, 2000). All these incantations are carried out in a special language usually based on excellence. Normally, this language is erected to domain the social body, installing subtle and effective actions of subjection, whose goals are control and perpetuation of this modus operandi.

This speech of 'passion' creates a libidinal tie that legitimates the individual to search in the organization the sense of its existence and a path that make it to be increasingly loved (FARIA, 2007). It can be inferred that, this organizational alienation conducts to an effective dictatorship of illusions and common ideal that covers the criticism. In this sedimentation of the paradigm existing, there is a difficulty to perceive the frontiers between personal and professional life (HANSEN, 2005), since the work is the main orderer of life. The organization assumes privileged place of identification, of projection and introjection (PAGÈS et al., 1987), being a space to be seized and vector of social interactions. It is provisionally admitted that, in principle, the centrality and identification assume a character of complacency and self-satisfaction.

\section{The Individual Caught in the Traps of Organizations' Social Control}

The evidences indicate that the individuals, partly, need a work that meets their aspirations and desires, leading them to achievement, contributing to form their personality. It must be pointed out that great part of individuals do not get a work that meet the conditions; then, the work can become degrading and can depersonalize them. The capacity to carry out useful things, establish and keep engagements, predict with others and for others, something that does not have binding directly to oneself (CLOT, 2006, p. 73).

These 'unsuspicious sufferings' related to the human life and work, can be classified as: a) singular suffering (diachronic dimension): inherited from psychic history of each individual; b) current suffering (synchronic dimension): occurs when there is reunion of the individual with work; c) creative suffering: when the subject produces solutions favorable to its life, specially for its health; d) pathogenic suffering: it is the opposite of creative suffering, that is, when the individual produces solution unfavorable to its life, and that are related to its health (DEJOURS, 1991, p. 154).

It can be understood that, the way to organize the work, the conditions for its achievement and the bonds generated are crucial to indicate the levels of wear existing in this process. There are two distinct orders to understand the psychic functioning at work, the factors of rational and cognitive nature, the individual's affective and relational dimension. When the work does not allow to the individuals a discharge of psychic tension, it has repercussions negatively on the worker (DEJOURS, 1996). 
The organization of work is the cause of a somatic weakening, as far as it can block the efforts of the worker to adequate the operating mode to the needs of its mental structure (DEJOURS, 1991). Clinically, the failure of the mental functioning and the inadequacy of work organization to the needs of the psychosomatic economy is not translated, immediately, into a somatic disease. In this condition, an experience of dissatisfaction arises, which is expressed, above all, by fatigue. The fatigue is simultaneously psychic and somatic (DEJOURS, 2007). The fatigue and the neurose of work ends up linking these last ones to true depressive statuses that, even being of lower severity, are becoming ever more numerous. When searching about the work neurosis, it is important to question if a work can be, in certain conditions, 'geno-depressive' (BUGARD \& CHOCQ, 1980).

Based on the above, besides all life quality programs in the organizations, the impact of the work content and the occupational environment evinces the relation between individual's physical and mainly psychic diseases and the overload that the requirements from the knowledge society are imposing to the workers. The human world was discarded and here, the work world is the one reduced to the intersubjective and social world. There is a strong reductionism in favor of the subjective, intra and intersubjective theater, and the interactions in terms of climate, leadership, motivation, gratification, power etc (DEJOURS, 2005, p. 33). The organizational sanity is an ideological instrument disguised, a pseudo-scientific resource, directed to the total inclusion of the individual in the organizational context (GUERREIRO RAMOS, 1981).

The notion of motivation itself is substituted by the more dynamic notion of suffering. 'The problematic of suffering allows realizing, in an equally satisfactory way, the motivation and pleasure at work and the demotivation and pathogenic effects' (DEJOURS, 2007, p. 161). The compulsive organization is a company turned in on itself. The status of people derives directly from the title of their position. The leadership dominates the organization from top to bottom, and requires an implacable conformity (KETS DE VRIES, 1997). Everything occurs as if 'life was strictly formalized and could be apprehended and controlled' (ENRIQUEZ, 1974, p. 54).

In the incessant search of the organization and ordering (the organization and ordering are necessary for all human activity), however, there is tendency to disconsider conflicts of the real as being part of other work activities (CLOT, 2006). It can really impede working, paradox that is typical of work organization currently.

Other relevant aspect to be consider in this environment, is that the organization repels individuals considered as volatile, which obligate them for maintenance of appearances, even understanding that the organizations cannot silence everybody. In a sense, it can be understood why organizations work so much the protection illusion, and great part of individuals in this environment cannot notice the psychic prison installed. In this perspective described, the spaces in the corporate environment are no longer oriented to the organizational goals, giving privilege the destructive narcissist individual goals. It is this dichotomy that reveals the 'fake connection' in the organizational actors' imagination. The flow of things is the accomplishment of their immanent standards and, therefore, results entirely from efficient and final causes. The flow of things is objectively conditioned by constructive data of the determined world and also by private experience of its purpose (GUERREIRO RAMOS, 1981).

To legitimate the organizations as a repository of heroes, full of bewildering actions and spectacular plays which generate great results, is reductionist and fallacious. The organizations has to offer to their actors only a small reference of part of the world, with mistakes and successes. The relations agglutinate themselves into dramaturgies, by building facets that reinforce wishes to transform their individual and organizational aspirations into something sumptuous and magnanimous, portraying an 'innocent makeup'. The existence of gestural and discursive aesthetics corroborates for the assembling of this 'theatrical stage', that commonly confuses what is real and fantasy. 'The normal man hides its real I in the transition with others, and tries to deny the existence of everything from its real I that does not have importance for the role performed' (JOURARD, 1964, p. 60-61 in GUERREIRO RAMOS, 1981).

It is projected an idealized idea, however, the organizational every day is permeated of defects and limitations. Even in the search for structuration that delineates predictability in organizational practices, what is verified is the presence of constant decisions non-programmed because of the environmental factors and the biggest organizational unknowns, the man. This idiosyncrasy allows the proliferation of the organizational environment propitious for heroic acting. The sensation of to want more is always present and is overvalued obligating the actors for filling social expectations present in 
the speeches. The diversity of interests and feelings characterizes the 'structure' of the informal organization, considering that interpersonal relations are associated. Thus, it is necessary contemplating the unconscious of individuals and the possible symbolic manifestations from a shared imagination (ENRIQUEZ, 2000). Nevertheless, the functional is present with the 'rational side of organizations', not allowing the proactive or reactive actor, with its features, establishes connection between the 'concave and convex', between emotion and reason, by configuring disorder and dysfunctions.

In the current context, the organizations give a speech of control and construction of world, however, the plasticity present in this environment reflects the transmission of a fake sensation that they always know the right way. Based on this conception, it can be noticed that it is impossible relativizing the speech given by organizations; it would be more realistic to assume the limits about what is desired. This set of images of exceptional qualities impregnated of status obligates that its actors run more and more each day to continue in the same place. In this dynamics, they are not owners, only tenants 'of this heaven' idealized and disguised in a unique goal: be the reflection of mirror.

\section{Perverted Manifestations of Work Centrality}

The work arises as a need for all individuals, even if it has distinct sense and distinguishes work and employment. The occupational behavior is a singular question of adjustment of individuals to their environment. The adjustment of sense of work is on the base of the humankind evolution process in the course of which arise the biological meanings of its own world and the sociocultural dimension. The evidences indicate that the work can be a primary need, fruit from motivation equally primary, or a need that can propitiate self-realization and self-esteem.

In the society of knowledge, there is each more difficulty to use adaptative mechanisms, which can be source of psychopathology, in case it is not in interaction with a task dully adapted to its fragility. In this new context, diseases as psychical fatigue, stress, depression, be as symptom of mismatch, or as primary clinical entity linked not only to threat feelings of financial security or to the loss of social status, but also of a vast framework of mismatches are part of the individuals' every day.

In this condition, from a theoretical approach among the writers mentioned in the following figure, it is possible to analyze several categories of analysis and their respective features of possible behavior of actors involved in the work organization in this performing ephemeral time:

\begin{tabular}{|c|c|}
\hline Category of analysis & Features \\
\hline Identity and work & $\begin{array}{l}\text { Loss of identity, absence of personal life, serial loneliness, unreachable ideal, } \\
\text { controlled subjectivity, flexibility. }\end{array}$ \\
\hline Nomadism & $\begin{array}{l}\text { Loneliness, indifference, liquidity of relations, agility, mobility, independence, } \\
\text { detachment, flexibility. }\end{array}$ \\
\hline Absence of personal ties & $\begin{array}{l}\text { Independence, individualism, liquidity of relations, loneliness, fictitious love, } \\
\text { fragile bindings, dynamism, deregulated schedules, mobility, conformism, non- } \\
\text { affiliated subject, indifference, work centrality, overvalue of work. }\end{array}$ \\
\hline Status & $\begin{array}{l}\text { Vanity, brilliance, superiority, proactivity, recognition and awards, power, be } \\
\text { unusual, comfort, social athlete. }\end{array}$ \\
\hline Standardized behaviors & $\begin{array}{l}\text { Passivity, defensive routines, collective ties of tenuous defense, disseminator, } \\
\text { methodism, overcoming limits, competitors, be always there, weakened } \\
\text { bindings; be performer, be unusual. }\end{array}$ \\
\hline Life as business & $\begin{array}{l}\text { Instability, unpredictability, performing time, pragmatism, profitability, } \\
\text { extravagance, immediate success, plasticity, permanent stress, winners with taste } \\
\text { for success. }\end{array}$ \\
\hline
\end{tabular}

Figure1. Category of analysis of the behavior of organizational actors in a performing ephemeral environment

Source: Adapted from Dejours, 1999; Gaulejac, 2007; Bauman, 2001; Freitas, 2000, 2005; Sennet, 2005, Gorz, 2005; Ehrenberg, 2010.

On this basis, it is right to say that the work not only continues to fill an exclusive psychological function, as it also keeps its centrality, being that the organization works to good part of actors, as a support point. In this condition, the painful and decisive experience of the real is unrolled for the subject, understood as what that in the work organization and in the task resists to its capacity, to its skills, to its control (CLOT, 2006, p. 59). 
In an environment each more competitive, in which watchwords as efficiency, efficacy and fulfilment are part of the daily atmosphere of work, when phenomenologically analyzed, it is revealed the culmination of a long situation of an 'unbearable' work. Thus, it is common that an authentic neurosis of work be installed, great part in reason of the worker be executed under unhealthy and unsafe conditions. The work carried out in this environment has effect on the welfare, both physical and psychical of individuals.

Thus, it should be stressed that the knowledge of the real work is possible only by means of individuals that carry out their tasks and of their experiences, about what they know and how they know. What exhausts them is the impeded activity, the one that returns, the impossible, and the one that cannot be carried out (CLOT, 2006). The intelligence of/at work, according to the psychodynamics of work, is featured by the cunning to which it is necessary other methods, before the difficulties found in practice (DEJOURS, 2007). The work must be able to establish commitments and can lose sense when does not allow achievement of vital goals and values that the subjects extract from different domains of life in which it is involved, because the work is, also, a mean of 'invention of these lives' (CLOT, 2006).

\section{Final Considerations}

Some of the effects pointed out in this work signalize that the individuals are falling ill each time at work, but few of them realize, even understanding that there are defense mechanisms. However, it is important emphasizing that the work is one of the greatest genders of social life in its set, a gender of situation of which a society can hardly step out without compromising its continuity; and of which a subject can hardly step aside without losing the feeling of social utility bonded to it (CLOT, 2006, p. 69).

The reality is elaboration of imagination, which is reflected in the artefacts, giving to the materiality the dimensions: symbolic (the think), the aesthetics (the conferred sense) and the own instrumentality (the act), however, submitting this locus to the domination and detailed control that instills selfvigilance. The individuals are afraid of becoming unproductive, useless and obsolete. In this perspective, the defensive strategies emerge, imprison and dominate by creating traps which catch the affective side of the actors, proposing an utilitarian ostensible and also fragile existence. Therefore, the individual lives its repression 'freely' (MARCUSE, 1975).

However, it is assumed that everything is subjective; then, it becomes illusory to aim it, that is, pleasure, achievements, sufferings, anguishes, among others; only are noticed as unfailing marks in the organizational dramas. In these dramas, the profitability and intensity are the recurrent worries to structure the free time, which infuses an illusion of truth to the 'liquid time' (BAUMAN, 2007). It is in this context, exposed in this essay, that is possible to notice the posture of some actors in the gaze, 'from the I to the world and from the world to the $I$, persistently seeking the originality or the abandon of this experience of human concreteness exacerbated, in which objectiveness can be translated in the time and in their tasks. The existing tension between the persistent search for originality must orient the actors from a subjective time, otherwise, the finality and sense of life lose importance, since the present starts materializing as absolute value of everything. In this perception, the actors must make use of creative tactics on the strategies of domination of the established power.

Thus, they can build a way that preserves them, at least in part, for themselves without losing their individuality. The life has been transformed and reduced, in this liquid society, (BAUMAN, 2004, 2007) into a cinematographic production, and the individuals are daily instilled to represent their role not as a coadjuvant, but, as the main actor, and, from this premise, be the lord of making of its life. In this perspective imposed, the fluidity of individuality becomes inevitable. At this moment it is noticed, an ideological instrument disguised, an appeal directed to the total inclusion of individual in this context.

In this configuration, Sísifo is materialized in few actors, condemning them to push incessantly 'this stone' until the top of the hill, only to see it roll down again. This is the painful metaphor of this performing time, that indicates how difficult seems to live this 'movie'. Great part of the organizational actors continues believing in miraculous proposals, without realizing how precarious is the contract based on the utility of things, on the quantification and on short term.

The fad of the world things is also reproduced in the organizations. Each fad with a life cycle each time shorter, but what does not mean that there is no demand to other new fads. It is not intended to 
set sail for generalizations, specially when it is considered the quantity of good works developed to avoid such trap, but it seems that many are 'deaf' in the search for the happiness, understood at this moment as a search of endless satisfaction in the succession of desires that alienates and imprisons. The dimensions of this syndrome put many organizational actors in a position of voluntary servitude (LA BOÉTIE, 1986, ENRIQUEZ, 1997), fruit of traps, individualism, libidinal hangover and existence ostensibly performance, of moveable, jubilant and mythical nature.

The aim of this article is not proving or refuting any theory, nor to suggest modifications, but to deconstruct the organizational imagination and its contradictory speeches about the work. In this conception, the concepts herein presented does not only reveal the organizations as a mosaic of performance social selves, but allow us to understand that the process of career and work become inescapably spectacular. In this performing condition, the organizations and its actors interpret, use, express meaning in their performances to reinvent themselves, in an idealized continuous flow. From this understanding, however, it can be established some parameters to decrease the discursive simulation and the violence at work, becoming more tenuous the overload that is inherent to this environment.

\section{REFERENCES}

ADORNO, T. W. Indústria cultural e sociedade. São Paulo: Paz e Terra, 2002.

HORKHEIMER, M. Dialética do esclarecimento: fragmentos filosóficos. Rio de Janeiro: Jorge Zahar, 1985.

BAUDRILLARD, J. La société de consimmation. Paris : Gallimard, 1970.

The virtual illusion: or the automatic of the word. Theory, Culture and Society, v. 12, 1995.

BAUMAN, Z. Modernidade líquida. Rio de Janeiro: Jorge Zahar, 2001.

Amor líquido: sobre a fragilidade dos laços humanos. Rio de Janeiro: Jorge Zahar, 2004.

Identidade. Rio de Janeiro: Jorge Zahar, 2005.

Tempos líquidos. Rio de Janeiro: Jorge Zahar, 2007.

BUGARD, L., CROCQ, L. Existe-t-il des névroses du travail?. Em Equilibre ou Fatigue par le travail. Paris: E.S.F., 1980.

CALLIGARIS, C. Perversão - um laço social? Salvador: Cooperativa Cultural Jacques Lacan, 1986.

CLEGG, S. Poder, linguagem e ação nas organizações. In: O indivíduo na organização: dimensões esquecidas. São Paulo: Atlas, 2007.

CLOT, Y. A função psicológica do trabalho. Petrópolis: Vozes, 2006.

DEBORD, G. Society of the spectacle. Detroit, Michigan, 1983.

DEJOURS, C. A loucura do trabalho: estudo de psicopatologia do trabalho. São Paulo: Cortez, 1991.

A carga psíquica do trabalho. In: DEJOURS, Christophe; ABDOUCHELI, Elisabeth; JAYET, Christian. Psicodinâmica do trabalho: contribuições da Escola Dejouriana à análise da relação prazer, sofrimento e trabalho. São Paulo: Atlas, 2007.

Subjetividade, trabalho e ação. Revista Produção, v. 14, nº 3, pp. 27-34, set./dez. 2004.

Uma nova visão do sofrimento humano nas organizações. In: CHANLAT, J.F., O indivíduo na organização: dimensões esquecidas. 3. ed. São Paulo: Atlas, 1996.

O fator humano. Rio de Janeiro: FGV, 2005.

ABDOUCHELI, E., JAYET, C. Psicodinâmica do trabalho: contribuições da Escola Dejouriana à análise da relação prazer, sofrimento e trabalho. São Paulo: Atlas, 2007.

EHRENBERG, A. O culto da performace: da aventura empreendedora à depressão nervosa. Aparecida: ideias e Letras, 2010.

ENRIQUEZ, E. Vida psíquica e organização. In: Vida psíquica e organização. Rio de Janeiro: FGV, 2000.

Da horda ao Estado: psicanálise do vínculo social. Rio de Janeiro: Jorge Zahar Editores, 1990.

O indivíduo preso na armadilha da estrutura estratégica. In: Vida psíquica e organização, Rio de Janeiro: Editora FGV, 2000.

Organização em análise. Petrópolis: Vozes, 1997. 
Imaginário social, recalcamento e repressão nas organizações. São Paulo: Tempo Brasileiro, 1974. FARIA, J.H. Economia política do poder: as práticas do controle nas organizações. Curitiba: Juruá, 2007.

FLEURY, M. T. L. Estórias, mitos, heróis: cultura organizacional e relações do trabalho. Revista de administração de empresas, v. 27, n. 4, p. 7-18, 1987.

FRANKL, V. E. Em busca de sentido: um psicólogo no campo de concentração. Petrópolis: Editora Vozes, 1991.

FREITAS, M.E. Contexto social e imaginário organizacional moderno. In: Revista de Administração de Empresas, São Paulo, v. 40, nº 2, 2000.

A questão do imaginário e a fronteira entre a cultura organizacional e a psicanálise. In: Vida psíquica e organização, Rio de Janeiro: FGV, 2000.

Cultura organizacional: identidade, sedução e carisma? Rio de Janeiro: FGV, 2006.

Existe uma saúde moral nas organizações. In: O\&S, v. 12, nº 32, Jan/Mar, 2005.

A mobilidade como novo capital simbólico nas organizações ou sejamos nômades? In: O\&S, v. 16, nº 49, Abr/Jun, 2009.

GAGLIARDI, P. Explorando o lado estético da vida organizacional. In: Handbook de estudos organizacionais: reflexões e novas direções. São Paulo: Atlas, 2001.

GASPARINI, G. Tempo e trabalho no ocidente. In: CHANLAT, J. O indivíduo na organização. São Paulo: Atlas, 2007.

GAULEJAC, V. Gestão como doença social: ideologia, poder gerencialista e fragmentação social. São Paulo: Ideias e Letras, 2007.

GORZ, A. O imaterial: conhecimento, valor e capital. São Paulo: Annablume, 2005.

GRISCI, C.L.I. Trabalho imaterial. In: CATTANI A.; HOLZMANN, L. (Orgs.). Dicionário de trabalho e tecnologia. Porto Alegre: UFRGS, 2006.

GUERREIRO RAMOS A. A nova ciência das organizações: uma reconceituação da riqueza das nações. Rio de Janeiro: FGV, 1981.

Administração e contexto brasileiro: esboço de uma teoria geral da administração. 2. ed. Rio de Janeiro: FGV, 1983.

HANSEN, R. S. Are you - or someone you know - a workaholic? In: Quintessential careers on line. Disponível em http://www.quintcareers.com. Acesso em: 15 maio 2014.

HARARI, Y. N. Sapiens: uma breve história da humanidade. Porto Alegre: L\&PM, 2015.

HARVEY, D. Condição pós-moderna. 7ª. ed. São Paulo: Edição Loyola, 1998.

HORKHEIMER, M. Eclipse da razão. São Paulo: Centauro, 2007.

KETS DE VRIES. M.F.R. Liderança na Empresa. São Paulo: Atlas, 1997.

LA BOÉTIE, E. Discurso sobre a servidão voluntária. Lisboa: Antígona, 1986.

LE BRETON, D. Adeus ao corpo: antropologia e sociedade. Campinas: Papirus, 2003.

LEEMING, David Adams (Ed.). The world of myth: an anthology. Oxford University Press, 1992.

LIPOVETSKY, G. A era do vazio: ensaio sobre o individualismo contemporâneo. Barueri: Manole, 2005.

LLOSA, M.V. A civilização do espetáculo. Rio de Janeiro: Objetiva, 2013.

MARCUSE, H. Eros e civilização: uma interpretação filosófica do pensamento de Freud. $6^{\text {a }}$ Ed. Rio de Janeiro: Zahar, 1975.

MELLARS, Paul. Why did modern human populations disperse from Africa ca. 60,000 years ago? A new model. Proceedings of the National Academy of Sciences, v. 103, n. 25, p. 9381-9386, 2006.

PAGÈS, M., BONETTI, M., GAULEJAC, V., DESCENDRE, D. O poder das organizações. São Paulo: Atlas, 1987.

PRESTES MOTTA, F.C. A propósito da sociedade organizacional. In: Revista de Administração de Empresas, Out/Dez, v.18, nº 4, 1978.

Organizações: vínculo e imagem. In: Revista de Administração de Empresas, Jul/Set, v. 31, nº 3, 1991. 
Gestão Contemporânea: a ciência e a arte de ser dirigente, 11. ed. São Paulo: Record, 2000.

Controle social nas organizações. In: Revista de Administração de Empresas. v. 33, nº 5, 1993.

Os pressupostos básicos de Schein e a fronteira entre psicanálise e a cultura organizacional. In: Vida psíquica e organização. Rio de Janeiro: FGV, 2000.

SENNETT, R. A corrosão do caráter: consequências pessoais do trabalho no novo capitalismo. 9. ed. Rio de Janeiro: Record, 2005.

A cultura do novo capitalismo. Rio de Janeiro: Record, 2006.

WILKINSON, R. G.; PICKETT, K. O nível: por que uma sociedade mais igualitária é melhor para todos. Rio de Janeiro: Civilização Brasileira, 2015.

WOOD Jr. T.; PAULA, A.P.P. Pop-Management: contos de paixão, lucro e poder. In: O \& S. v. 9, nº 24, maio/agosto, 2002.

TONELLI, M.J.; COOKE, B. A colonização e a neo-colonização dos recursos humanos no Brasil. In: Revista de Administração de Empresas, v. 51, nº 3, maio/jun 2011.

\section{AUTHORS' BIOGRAPHY}

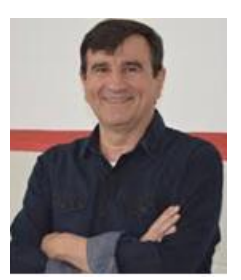

Carlos César Ronchi, Graduated in Economics at the Universidade Regional de Blumenau (FURB), Postgraduate in Marketing at the Universidade Regional de Blumenau (FURB), Master Degree in Management from Universidade Federal de Santa Catarina (UFSC). Professor of undergraduate and graduate students at the Universidade Ceuma (CEUMA). Member of GPS (Research Group on Management and Society).

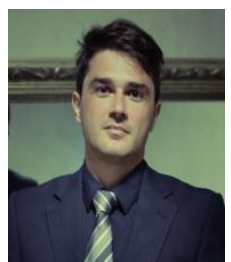

Mauro Enrique Carozzo Todaro, Graduated in Industrial Engineering at the Universidad Nacional de Rosario (UNR), Master Degree in Management from Universidade Federal de Santa Catarina (UFSC) and Doctor Degree in Management from the Universidad Carlos III de Madrid (UC3M). Professor at the Department of Mechanical and Industrial Engineering, and Planning Director of the Universidade Estadual do Maranhão (UEMA). 